\title{
Seasonal dynamics in nitrous oxide emissions under different types of vegetation in saline-alkaline soils of the Yellow River Delta, China and implications for eco-restoring coastal wetland
}

\author{
Lihua Zhang ${ }^{\mathrm{a}, 1}$, Luping Song a,c,1, Liwen Zhang a ${ }^{\mathrm{a}}$ Hongbo Shao ${ }^{\mathrm{a}, \mathrm{b}, *, 1}$, \\ Xiaobing Chen ${ }^{a}$, Kun Yan ${ }^{a}$ \\ ${ }^{a}$ Key Laboratory of Coastal Biology E Bioresources Utilization, Yantai Institute of Coastal Zone Research (YIC), Chinese Academy of Sciences (CAS), Yantai \\ 264003, China \\ b Institute for Life Sciences, Qingdao University of Science E Technology (QUST), Qingdao 266042, China \\ ${ }^{\mathrm{c}}$ The Graduate University of Chinese Academy of Sciences, Beijing 100049, China
}

\section{A R T I C L E I N F O}

\section{Article history:}

Received 16 July 2013

Accepted 20 September 2013

Available online 26 October 2013

\section{Keywords:}

Greenhouse gas

Yellow River Delta

Saline-alkaline soils

Nitrous oxide

Coastal wetland

\begin{abstract}
A B S T R A C T
Salt-affected soils are extensively present and constitute about 7\% of total land surface. However, our knowledge about nitrous oxide $\left(\mathrm{N}_{2} \mathrm{O}\right)$ production through rapid nitrification and denitrification processes between the atmosphere and the saline soil is very limited. In order to evaluate the potential of $\mathrm{N}_{2} \mathrm{O}$ consumption in saline soils, this study was therefore designed to quantify the variability in $\mathrm{N}_{2} \mathrm{O}$ emissions monthly in the Yellow River Delta in China. Main issues include: different saline-alkaline soils and temporal aspects. Our aim was to quantify $\mathrm{N}_{2} \mathrm{O}$ emissions and identify the major drivers controlling its emissions for providing guidance in eco-restoring coastal wetland on large scale. By using in situ closed chambers the annual average emissions of $\mathrm{N}_{2} \mathrm{O}$ from the mudflat was determined and it was significantly higher than plant communities, especially herbage communities. In general, the emissions of $\mathrm{N}_{2} \mathrm{O}$ of different ecosystems showed a unique-peak annual pattern, with the peak in September. Saline-alkaline mudflat and different vegetations acted as $\mathrm{N}_{2} \mathrm{O}$ source in the Yellow River Delta and the $\mathrm{N}_{2} \mathrm{O}$ emission of different ecosystems followed the order: Saline-alkaline mudflat $>T$. chinensis $>S$. salsa $>P$. australis Therefore restoration of saline land through revegetation was necessary to reduce the $\mathrm{N}_{2} \mathrm{O}$ emission of saline soils. The effects of air and soil temperature on $\mathrm{N}_{2} \mathrm{O}$ fluxes were significant in salt-affected soils except $P$. australis. Soil water content and electrical conductivity correlated positively or negatively with $\mathrm{N}_{2} \mathrm{O}$ emissions in mudflat and $P$. australis community. While relationships between $\mathrm{N}_{2} \mathrm{O}$ production and other soil properties (TC, TN, C:N ratio, $\mathrm{NH}_{4}{ }^{-}-\mathrm{N}$ and $\mathrm{NO}_{3}{ }^{-}-\mathrm{N}$ ) were only significant in mudflat and $T$. chinensis community. Temporal variations of $\mathrm{N}_{2} \mathrm{O}$ emission were related to the interactions of abiotic factors (air and soil temperature, soil water content and electrical conductivity) and the variations of other soil properties, while spatial variations were mainly affected by the vegetation composition at spatial scale.
\end{abstract}

(C) 2013 Elsevier B.V. All rights reserved.

\section{Introduction}

Atmospheric nitrous oxide $\left(\mathrm{N}_{2} \mathrm{O}\right)$ concentrations have been increasing since the industrial revolution and currently account for $6 \%$ of total anthropogenic radiative component and is becoming the main cause of stratospheric ozone destruction (Davidson, 2009). The increase in its atmospheric concentration is attributed mainly to anthropogenic activities, such as deforestation, agricultural

\footnotetext{
* Corresponding author at: Institute for Life Sciences, Qingdao University of Science \& Technology (QUST), Qingdao 266042, China. Tel.: +86 5352109191.

E-mail address: shaohongbochu@126.com (H. Shao).

1 These authors contributed to the work equally.
}

practices and fossil fuels combustion. Besides, a considerable amount of atmospheric $\mathrm{N}_{2} \mathrm{O}$ is produced and consumed in soils by microbial processes of nitrification, denitrification and nitrifierdenitrification (Davidson et al., 2000; IPCC, 2001).

It is widely accepted that the emissions of soil $\mathrm{N}_{2} \mathrm{O}$ is highly variable and strongly influenced by environmental factors, such as soil properties and moisture (Davidson et al., 1993; Breuer et al., 2000). Additionally, to understand of how soil properties and moisture regulate $\mathrm{N}_{2} \mathrm{O}$ emission is essential for realistic predicting soil-atmosphere N trace gas exchange (Gharahi Ghehi et al., 2012).

Soil management and environmental conditions directly influence $\mathrm{N}_{2} \mathrm{O}$ production, which leads to land use to clearly influence $\mathrm{N}_{2} \mathrm{O}$ emissions (Maljanen et al., 2003). Cultivated and uncultivated wetlands have been shown to emit $\mathrm{N}_{2} \mathrm{O}$ at significantly different 
rates over the same period according to previous study (BedardHaughn et al., 2006). So $\mathrm{N}_{2} \mathrm{O}$ emissions may vary with different vegetation communities.

Seasonal variation in plant growth and environmental factors and seasonal fluctuations likely lead to significant temporal variation in $\mathrm{N}_{2} \mathrm{O}$ fluxes of soils (Kachenchart et al., 2012). For example, organic matter break-down and $\mathrm{NO}_{3}{ }^{-}$production could be stimulated in dry warm seasons, and the loss of $\mathrm{N}_{2} \mathrm{O}$ may be induced in the subsequent wet season when waterlogging occurs (Dalal et al., 2003; Liu et al., 2012).

Salt-affected soils are extensively present and covers approximately $7 \%$ of the world land area (Ghassemi et al., 1995). Because of the high water table and the potential for reducing conditions that prevail in salt-affected soils, significant losses of $\mathrm{N}$ could occur via denitrification, making salt-affected soils potential hotspots for $\mathrm{N}_{2} \mathrm{O}$ emission. On the other hand, our knowledge about $\mathrm{N}_{2} \mathrm{O}$ turnover between the atmosphere and the saline soils are very limited. In this study, we investigated $\mathrm{N}_{2} \mathrm{O}$ emissions of naturally saline soils in the Yellow River Delta.

The Yellow River Delta (YRD) is the fastest growing delta and the most active land-ocean interaction regions among the large river deltas in the world (Wang et al., 2012), because the Yellow River brings great quantities of muddy sand into the Bohai Sea. YRD lied at Bohai sea gulf, is one of the three biggest deltas in China. Total land area covered $12,000 \mathrm{~km}^{2}$, while averagely $0.5 \mathrm{hm}^{2}$ per capita, arable land was $0.19 \mathrm{hm}^{2}$ per capita in the region. The YRD is called as the "Golden Triangle" due to its great exploitation potential and development of the YRD, it gets more and more attention. However, here rainfall was less and the mineral content in underground water was higher. These conditions caused soil salinization and alkalization. Therefore land degradation was a typical case in the field. Through analysis of land use, land cover change and driving force in YRD, it could be concluded that these natural factors such as more evaporation, less rainfall, poorer fresh water hindered land use regularly. Soil salinization was easily going to occur. Meanwhile, the variety of Yellow River hydrology and human disturbances of land environmental have also been important driving factors (Xing and Zhang, 2006).

Tamarix chinensis, Suaeda salsa and Phragmites australis were three dominant plant species adapt the saline-alkaline habitat in YRD region. Even though variations in soil properties and moisture are considered as the main driver of $\mathrm{N}_{2} \mathrm{O}$ emissions, it does not explain observed temporal and spatial variations in salinealkaline soils of YRD. The current study tried to quantify the $\mathrm{N}_{2} \mathrm{O}$ source/strength of different saline soils using high resolution data, and examine in detail, the principal environmental characteristics that control $\mathrm{N}_{2} \mathrm{O}$ fluxes. The objectives of this study were (i) to study the diurnal variability of soil-atmosphere exchange of $\mathrm{N}_{2} \mathrm{O}$ in saline-alkaline soils of the Yellow River Delta and (ii) to investigate the relationship between soil $\mathrm{N}_{2} \mathrm{O}$ flux and dynamic soil physiochemical properties to understand the driving environmental factors and processes so as to aid the future development of process-based models of saline-alkaline biogeochemical function and eco-restoration. Studying these remaining remnant pockets will provide 'baseline' greenhouse gas emissions, critical data when determining the greenhouse gas budget as a result of land use change.

\section{Materials and methods}

\subsection{Study site}

This study was conducted in the Yellow River Estuary, located in the Nature Reserve of the Yellow River Delta $\left(37^{\circ} 35^{\prime}-38^{\circ} 12^{\prime} \mathrm{N}\right.$, $118^{\circ} 33^{\prime}-119^{\circ} 20^{\prime}$ E) in Dongying City, Shandong Province, China. The nature reserve has a typical continental monsoon climate with distinctive seasons; summer is warm and rainy while winter is cold. The annual average temperature is $12.1^{\circ} \mathrm{C}$, the frost-free period is 196 days, and the effective accumulative temperature is about $4300^{\circ} \mathrm{C}$. Annual evaporation is $1962 \mathrm{~mm}$ and annual precipitation is $551.6 \mathrm{~mm}$, with about $70 \%$ of precipitation occurring between June and August. The soils in the study area are dominated by intrazonal tidal soil and salt soil (Tian et al., 2005; Mou et al., 2011).

\subsection{Experiment design}

The present study was carried out monthly from April to December 2012. We selected the no vegetation saline-alkaline soil, T. chinensis community, S. salsa community and P. australis community as four observation sites, which were less than $100 \mathrm{~m}$ apart. All the observations were conducted in triplicate with the mean value being analyzed. Because of limitations on labor and equipment, observations for these four types were not conducted on the same date, but the replicates were observed at the same time period on the same day. On each sampling date, measurements were conducted at 7:00, 9:00, 11:00, 13:00, 15:00 and 17:00.

\subsection{Measurement method}

Fluxes of $\mathrm{N}_{2} \mathrm{O}$ were measured using static dark chamber and gas chromatography techniques. The static chamber was made of stainless steel and consisted of two parts. Before observation, one square box (without a top and bottom, length $\times$ width $\times$ height $=0.5 \mathrm{~m} \times 0.5 \mathrm{~m} \times 0.2 \mathrm{~m}$ ), serving as a collar for supporting chamber the sampling chamber, was inserted directly into the soil with $5 \mathrm{~cm}$ exposed above the soil surface and kept in the soil during the entire experiment. During our observations, the chamber (without bottom, length $\times$ width $\times$ height $=0.5 \mathrm{~m} \times 0.5 \mathrm{~m} \times 0.7 \mathrm{~m}$ ) was placed into the collar with water to prevent leakage and the vegetation was included within the chamber. In order to maintain a consistent temperature within the chamber, we wrapped the cylinder with a quilt. Inside the chamber, a small fan that was used to stir the air and a thermometer sensor and a trinal-venthole were installed. Gas sampling usually lasted one hour because we took four gas samples in 20-min intervals, and samples were collected with an injector with a $60 \mathrm{ml}$ capacity via a Teflon tube connected to the chamber.

The gas samples were stored in dark cool bags less than $24 \mathrm{~h}$ before being measured. Gas chromatography was used to measure the gas concentrations; then the gradient of gas concentration during sampling was used to calculate the gas flux between ecosystems and the atmosphere. Positive values mean the flux from ecosystems to the atmosphere, and negative values mean the flux from the atmosphere to ecosystems.

The gas samples were analyzed using a gas chromatogram (Agilent 7890A, Agilent Co., Santa Clara, CA, USA) within $24 \mathrm{~h}$ (Song et al., 2009).

The gas flux was calculated according to the following equation from Song et al. (2008)

$F=\frac{d c}{d t} \frac{M}{V_{0}} \frac{P}{P_{0}} \frac{T_{0}}{T} H$

where the $\mathrm{d} c / \mathrm{d} t$ is the slope of the gas concentration curve variation, along with time. $M$ is the mole mass of each gas. $P$ is the atmospheric pressure in the sampling site. $T$ is the absolute temperature during the sampling. $V_{0}, T_{0}, P_{0}$ are the gas mole volume, air absolute temperate and atmospheric pressure under standard 

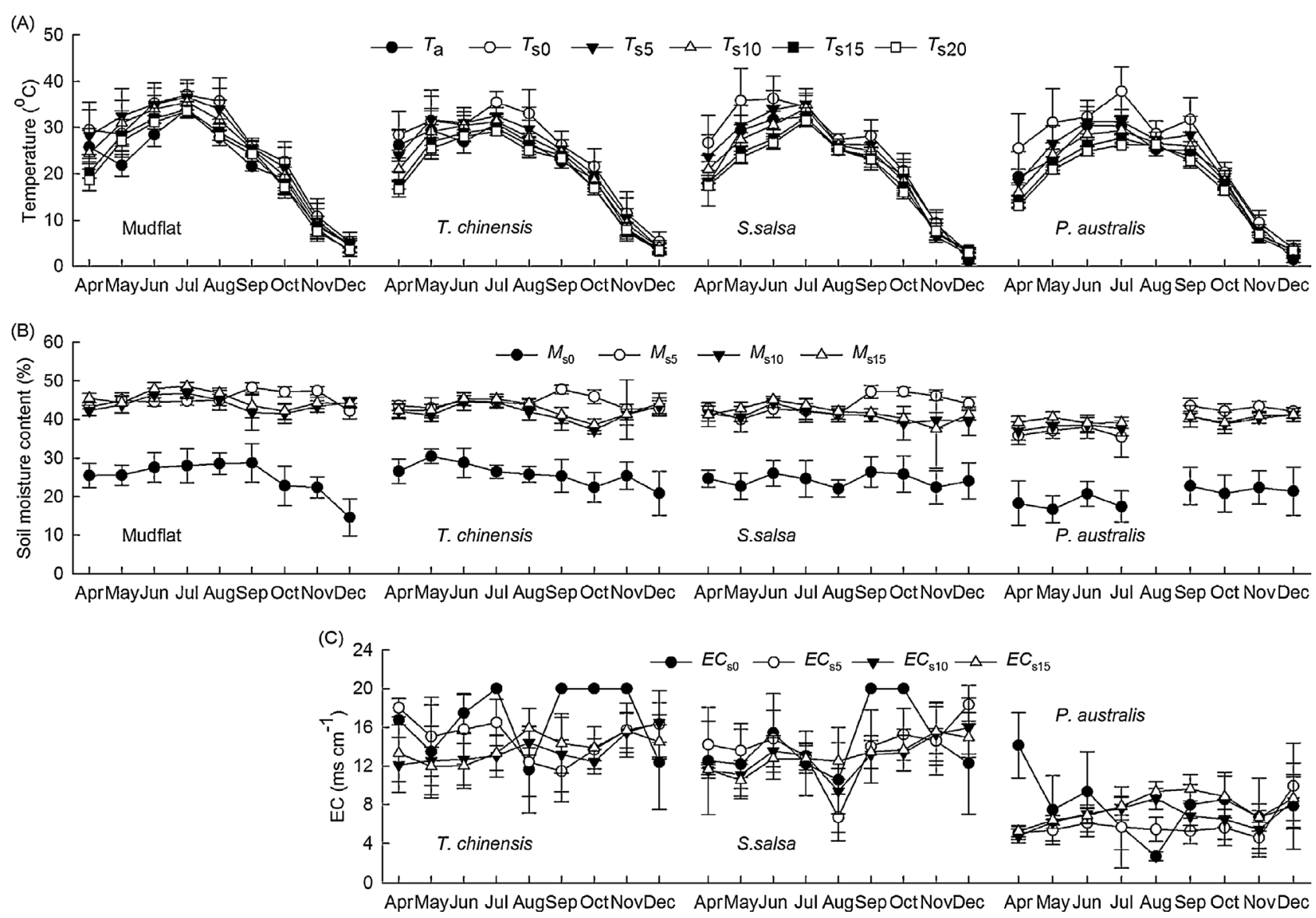

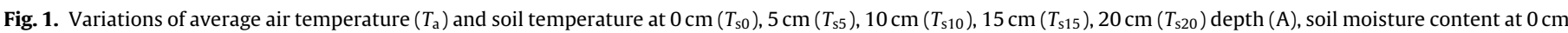

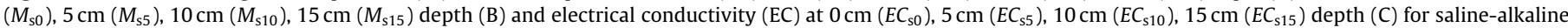
mudflat and different vegetation types.

conditions, respectively. $H$ is the height of the chamber during sampling.

\subsection{Environmental measurement}

At the same time that gas measurements were conducted, we also measured the air temperature inside and outside the chambers, atmospheric pressure. Soil temperatures were measured at $5-\mathrm{cm}$ intervals from soil surface to $20 \mathrm{~cm}$ depth. Soil volumetric moisture and electrical conductivity (EC) $(0,5,10$ and $15 \mathrm{~cm}$ depths) were determined in situ by high-precision moisture measuring instrument (AZS-2) and soil and solution EC meter (Field Scout), respectively. Soil EC of mudflat was not determined since the values beyond the pale of the EC meter. On each sampling date, two soil samples $(0-10 \mathrm{~cm}$ and $10-20 \mathrm{~cm})$ per site were taken for analyzing TC and TN contents by element analyzer (Elementar Vario Micro, German) and $\mathrm{NH}_{4}{ }^{+}-\mathrm{N}$ and $\mathrm{NO}_{3}{ }^{-}-\mathrm{N}$ contents by sequence flow analyzer (AutoAnalyzer III, Germany).

\subsection{Statistical analysis}

Repeated measures analysis of variance (ANOVA) was used to examine the site- and temporal-variation in $\mathrm{N}_{2} \mathrm{O}$ fluxes. One-way ANOVA was employed to examine the difference in the mean $\mathrm{N}_{2} \mathrm{O}$ fluxes among the four saline sites. Correlation analysis was used to examine the relationships of $\mathrm{N}_{2} \mathrm{O}$ fluxes with air temperature, soil temperature at different depths, soil water content and electrical conductivity at different soil depths. All the analyses passed the normality test without the transformation of the original data. Statistical significance was accepted when $P<0.05$. All statistical analyses were performed using SPSS for Windows 20.0.

\section{Results}

\subsection{Environmental variables under different vegetation types}

During all times of the seasons measured, air temperature and soil temperatures did not differ between positions. They both increased from April to July, then decreased gradually (Fig. 1A). Although water contents in subsurface soil were higher than those in surface soil, no significant differences were found among the four positions and different soil depths (Fig. 1B). Both EC in surface and subsurface soil $(5,10$ and $15 \mathrm{~cm})$ had no significant difference between $T$. chinensis and $S$. salsa communities, but they both higher than those in $P$. australis community. The air and soil temperatures in mudflat and different vegetation communities both showed single-peak curves and the maximum occurred in July. No significant difference in water content and EC was found among different seasons.

Total $\mathrm{C}$ and Total $\mathrm{N}$ in surface $(0-10 \mathrm{~cm})$ and subsurface soils had significant differences among the four communities, in the order of $P$. australis $>S$. salsa $>T$. chinensis $>$ mudflat (Fig. $2 \mathrm{~A}$ and B). TC and $\mathrm{TN}$ in surface soil were higher than those in subsurface in different vegetation communities, but no significant difference between surface and subsurface was found in mudflat. The soil C:N ratio had no significant difference between surface and subsurface in 


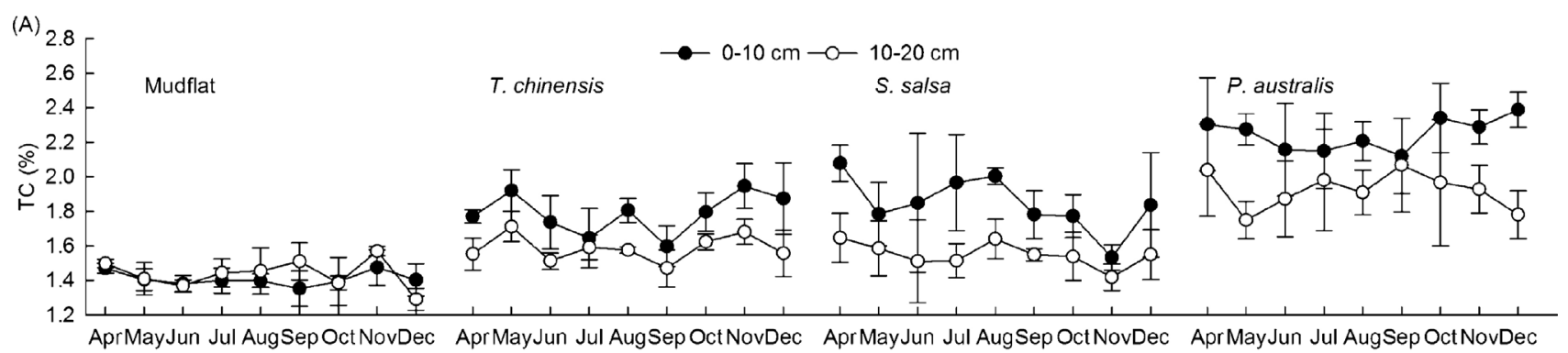

(B)
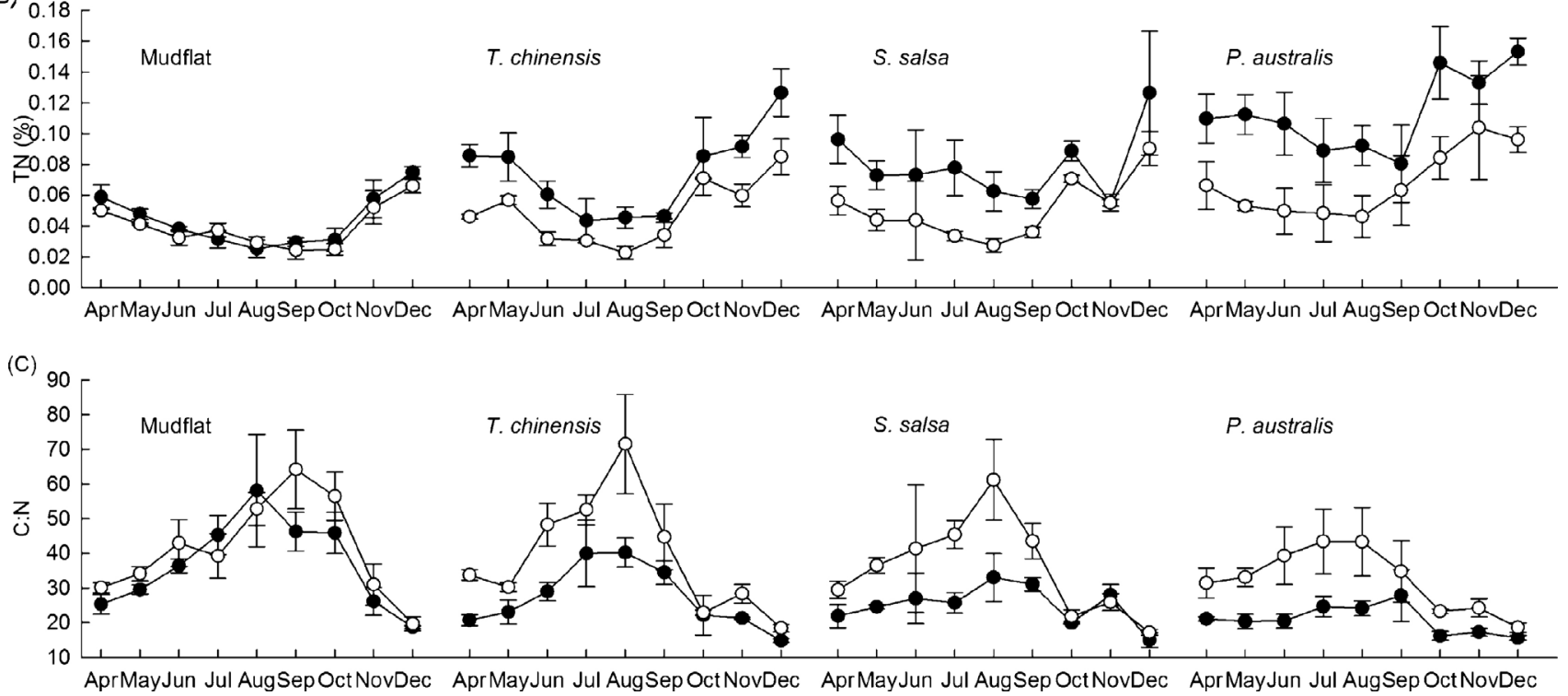

Fig. 2. Variations of TC (A), TN (B) and C:N ratio (C) for saline-alkaline mudflat and different vegetation types.

mudflat, but in surface were significant lower than those in subsurface in different vegetation communities, and in the order of $P$. australis $<$ S. salsa $<$ T. chinensis $<$ mudflat (Fig. 2C). There had no significant difference among varied months for TC content and
TN content decreased from April to August or September, then increased in mudflat and all vegetation communities. Accordingly, the $\mathrm{C}: \mathrm{N}$ ratios of soil surface and subsurface increased until August or September, then decreased.
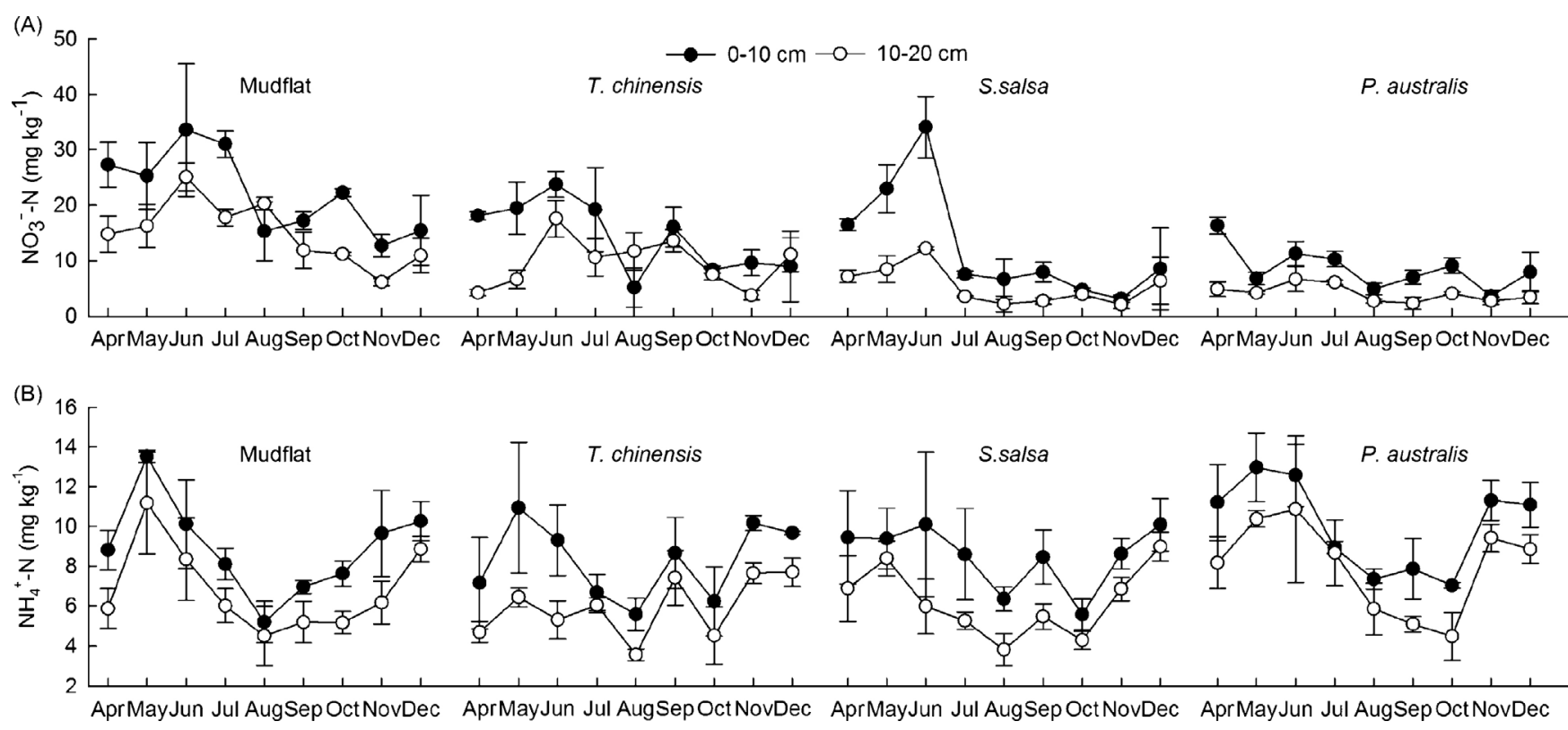

Fig. 3. Variations of $\mathrm{NO}_{3}{ }^{-}-\mathrm{N}(\mathrm{A})$ and $\mathrm{NH}_{4}{ }^{+}-\mathrm{N}(\mathrm{B})$ contents for saline-alkaline mudflat and different vegetation types. 


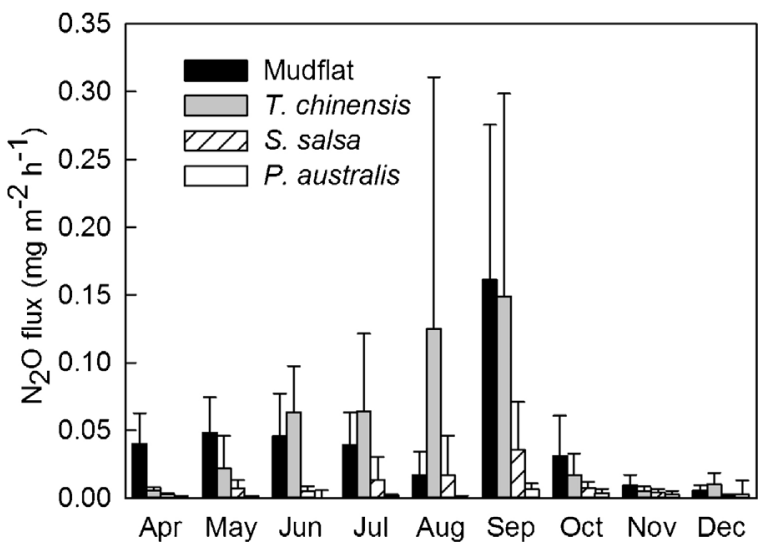

Fig. 4. Annual $\mathrm{N}_{2} \mathrm{O}$ flux for saline-alkaline mudflat and different communities.

Similar with TC and $\mathrm{TN}, \mathrm{NO}_{3}{ }^{-}-\mathrm{N}$ and $\mathrm{NH}_{4}{ }^{+}-\mathrm{N}$ in surface soil were higher than those in subsurface in mudflat and different vegetation communities. The $\mathrm{NO}_{3}{ }^{-}-\mathrm{N}$ content had significant differences among the four communities, followed the order: $P$. australis $<S$. salsa $<$ T. chinensis $<$ mudflat (Fig. 3A), no significant differences was found among the four positions for $\mathrm{NH}_{4}{ }^{+}-\mathrm{N}$ content (Fig. 3B). In general, $\mathrm{NO}_{3}{ }^{-}-\mathrm{N}$ and $\mathrm{NH}_{4}{ }^{+}-\mathrm{N}$ contents in surface and subsurface soils were highest in June and May, respectively, then decreased, and were lowest in August.

\subsection{Seasonal variation of $\mathrm{N}_{2} \mathrm{O}$ flux from different vegetation}

Over all sampling periods, $\mathrm{N}_{2} \mathrm{O}$ fluxes of mudflat, $T$. chinensis, S. salsa and $P$. australis communities ranged from 0.0056 to $0.1611 \mathrm{mg} \mathrm{m}^{-2} \mathrm{~h}^{-1}$, from 0.0049 to $0.1490 \mathrm{mg} \mathrm{m}^{-2} \mathrm{~h}^{-1}$, from 0.0008 to $0.0357 \mathrm{mg} \mathrm{m}^{-2} \mathrm{~h}^{-1}$ and from 0.0002 to $0.0066 \mathrm{mg} \mathrm{m}^{-2} \mathrm{~h}^{-1}$, respectively (Fig. 4). The annual average fluxes of $\mathrm{N}_{2} \mathrm{O}$ in above four positions were $0.0442 \mathrm{mg} \mathrm{m}^{-2} \mathrm{~h}^{-1}$, $0.0512 \mathrm{mg} \mathrm{m}^{-2} \mathrm{~h}^{-1}, 0.0103 \mathrm{mg} \mathrm{m}^{-2} \mathrm{~h}^{-1}$ and $0.0021 \mathrm{mg} \mathrm{m}^{-2} \mathrm{~h}^{-1}$, indicating that different saline-alkaline soils acted as $\mathrm{N}_{2} \mathrm{O}$ source. The $\mathrm{N}_{2} \mathrm{O}$ fluxes of mudflat and $T$. chinensis community were significantly higher than $S$. salsa and $P$. australis communities.

$\mathrm{N}_{2} \mathrm{O}$ emissions in different ecosystems both showed single-peak curves and the maximum occurred in September.

\subsection{Correlation between $\mathrm{N}_{2} \mathrm{O}$ emissions and environmental variables}

Pearson correlation analysis between $\mathrm{N}_{2} \mathrm{O}$ fluxes and independent variables in the four positions were conducted (Table 1 ). In $P$. australis community, $\mathrm{N}_{2} \mathrm{O}$ fluxes had no significant correlations with air and soil temperature in surface and subsurface soils, while significant positive correlations were found in other three positions. $\mathrm{N}_{2} \mathrm{O}$ emissions in mudflat indicated a notable positive correlation with water content and EC of soil surface, $5 \mathrm{~cm}$ soil water content, and soil C: $\mathrm{N}$ ratio in $10-20 \mathrm{~cm}$ depth and a negative correlation with soil $\mathrm{TN}$ and $10 \mathrm{~cm}$ soil water content. In $T$. chinensis community, $\mathrm{N}_{2} \mathrm{O}$ fluxes was negatively correlated with soil $\mathrm{TN}$, but positively correlated with $\mathrm{NO}_{3}{ }^{-}-\mathrm{N}$ at $10-20 \mathrm{~cm}$ depth and C: $\mathrm{N}$ ratio at $0-10 \mathrm{~cm}$ depth. $\mathrm{N}_{2} \mathrm{O}$ fluxes from $S$. salsa had no significant correlation with environment parameters, with the exception of temperature. A significant positive correlation was apparent between $\mathrm{N}_{2} \mathrm{O}$ emission and $5 \mathrm{~cm}$ and $10 \mathrm{~cm}$ water content, $15 \mathrm{~cm}$ soil EC in P. australis community.
Table 1

Pearson correlation analysis between $\mathrm{N}_{2} \mathrm{O}$ fluxes and environmental parameters.

\begin{tabular}{|c|c|c|c|c|}
\hline Environmental parameters & Mudflat & T. chinensis & S. salsa & P. australis \\
\hline \multicolumn{5}{|l|}{ Temperature } \\
\hline Air & $0.192^{*}$ & $0.217^{* *}$ & $0.201^{*}$ & -0.029 \\
\hline Soil surface & $0.181^{*}$ & $0.284^{* *}$ & $0.171^{*}$ & -0.017 \\
\hline Soil $5 \mathrm{~cm}$ & $0.200^{*}$ & $0.297^{* *}$ & $0.196^{*}$ & -0.033 \\
\hline Soil $10 \mathrm{~cm}$ & $0.403^{* *}$ & $0.305^{* *}$ & $0.249^{* *}$ & -0.040 \\
\hline Soil $15 \mathrm{~cm}$ & $0.226^{* *}$ & $0.311^{* *}$ & $0.244^{* *}$ & -0.044 \\
\hline Soil $20 \mathrm{~cm}$ & $0.371^{* *}$ & $0.307^{* *}$ & $0.274^{* *}$ & -0.048 \\
\hline \multicolumn{5}{|l|}{ Water content } \\
\hline Soil surface & $0.248^{*}$ & 0.006 & -0.019 & 0.121 \\
\hline Soil $5 \mathrm{~cm}$ & $0.399^{* *}$ & 0.181 & 0.133 & $0.314^{* *}$ \\
\hline Soil $10 \mathrm{~cm}$ & -0.250 & 0.148 & 0.003 & $0.253^{*}$ \\
\hline Soil $15 \mathrm{~cm}$ & -0.189 & 0.057 & 0.000 & -0.052 \\
\hline \multicolumn{5}{|l|}{ Electrical conductivity } \\
\hline Soil surface & $0.629^{*}$ & -0.249 & 0.197 & 0.074 \\
\hline Soil $5 \mathrm{~cm}$ & -0.435 & -0.120 & -0.050 & -0.127 \\
\hline Soil $10 \mathrm{~cm}$ & -0.205 & -0.046 & -0.067 & 0.065 \\
\hline Soil $15 \mathrm{~cm}$ & -0.334 & 0.185 & -0.009 & $0.282^{* *}$ \\
\hline \multicolumn{5}{|l|}{ TC } \\
\hline $0-10 \mathrm{~cm}$ & -0.107 & -0.349 & -0.107 & -0.048 \\
\hline $10-20 \mathrm{~cm}$ & 0.015 & -0.354 & -0.038 & 0.100 \\
\hline \multicolumn{5}{|l|}{ TN } \\
\hline $0-10 \mathrm{~cm}$ & $-0.394^{*}$ & $-0.592^{* *}$ & -0.347 & -0.110 \\
\hline $10-20 \mathrm{~cm}$ & $-0.591^{* *}$ & $-0.457^{*}$ & -0.348 & 0.158 \\
\hline \multicolumn{5}{|l|}{$\mathrm{NH}_{4}{ }^{+}-\mathrm{N}$} \\
\hline $0-10 \mathrm{~cm}$ & -0.176 & -0.266 & -0.212 & -0.371 \\
\hline $10-20 \mathrm{~cm}$ & -0.167 & 0.016 & -0.379 & -0.330 \\
\hline \multicolumn{5}{|l|}{$\mathrm{NO}_{3}{ }^{-}-\mathrm{N}$} \\
\hline $0-10 \mathrm{~cm}$ & -0.128 & 0.107 & -0.069 & -0.145 \\
\hline $10-20 \mathrm{~cm}$ & -0.023 & $0.589^{* *}$ & -0.196 & -0.191 \\
\hline \multicolumn{5}{|l|}{ C:N ratio } \\
\hline $0-10 \mathrm{~cm}$ & 0.245 & $0.575^{* *}$ & 0.338 & 0.126 \\
\hline $10-20 \mathrm{~cm}$ & $0.680^{* *}$ & 0.364 & 0.349 & -0.108 \\
\hline
\end{tabular}

* Significance of $p<0.05$.

Significance of $p<0.01$.

\section{Discussion}

In this study, a clear annual pattern of $\mathrm{N}_{2} \mathrm{O}$ emissions from saline-alkaline mudflat and vegetations in the Yellow River Delta were observed. We found that high $\mathrm{N}_{2} \mathrm{O}$ emissions occurred during summer and autumn and low fluxes occurred during spring and winter. The results were similar with others (Søvik and Kløve, 2007; Wang et al., 2007).

Annual changes in solar energy input and associated temperature changes are the most important factors, although there are several interacting mechanisms that are involved in controlling the annual variation in $\mathrm{N}_{2} \mathrm{O}$ net fluxes (Long et al., 2010). The effects of soil temperature on soil $\mathrm{N}_{2} \mathrm{O}$ fluxes are also well known and have been demonstrated for several types of ecosystem (Klemedtsson et al., 1997; Regina et al., 1999).

$\mathrm{N}_{2} \mathrm{O}$ fluxes tend to correlate with soil temperature, because microbiological processes regulate the production and consumption of $\mathrm{N}_{2} \mathrm{O}$ in soil (Sahrawat and Keeney, 1986). Correlation analysis in the current study showed that there did not exist a significant relationship between air or soil temperatures and $\mathrm{N}_{2} \mathrm{O}$ emissions in $P$. australis community, but the significant relationship between $\mathrm{N}_{2} \mathrm{O}$ emissions and temperature was found in other three positions. Tang et al. (2006) suggested that soil temperature did not have a strong effect on $\mathrm{N}_{2} \mathrm{O}$ emissions, which was consistent with results reported in tropical, agricultural soils (Crill et al., 2000; Kiese and Butterbach-Bahl, 2002). On the other hand, some studies showed that $\mathrm{N}_{2} \mathrm{O}$ fluxes were strongly correlated with soil temperature. Zhu et al. (2008) indicated that $\mathrm{N}_{2} \mathrm{O}$ emission peaks coincided with the maximum of ground temperature in coastal tundra marsh of eastern Antarctica. Schaufler et al. (2010) and Schindlbacher et al. (2004) have also shown that $\mathrm{N}_{2} \mathrm{O}$ emissions increase exponentially 
with increasing soil temperature. So $\mathrm{N}_{2} \mathrm{O}$ emissions may vary with different ecosystems.

$\mathrm{N}_{2} \mathrm{O}$ is mostly produced through nitrification, de-nitrification, nitrifier- denitrification and dissimilatory reduction of $\mathrm{NO}_{3}{ }^{-}$to $\mathrm{NH}_{4}{ }^{+}$in soil (Wrage et al., 2001; Smith et al., 2003). Soil moisture has been identified as the most sensitive factor to regulate $\mathrm{N}_{2} \mathrm{O}$ emissions from soils since it directly regulates oxygen availability in soil pores, which determines the activity of nitrification and denitrification within the soil profile (Zheng et al., 2000; Silva et al., 2008). Small changes of soil water content can significantly affect $\mathrm{N}_{2} \mathrm{O}$ emission (Cai et al., 2001; Grant and Pattey, 2003; Smith et al., 2003). At 40\% water-holding capacity, anaerobiosis in unamended soil was small or non-existent so production of $\mathrm{N}_{2} \mathrm{O}$ was mainly due to nitrification (Stevens et al., 1998). Increases in $\mathrm{H}_{2} \mathrm{O}$ content will reduce $\mathrm{O}_{2}$ concentration, induce nitrifier- denitrification and denitrification and thus production of $\mathrm{N}_{2} \mathrm{O}$ and $\mathrm{N}_{2}$ (Silva et al., 2008; Zhang et al., 2013). This is consistent with a similar study in humid temperate regions of southern Europe where $\mathrm{N}_{2} \mathrm{O}$ production was limited by soil water content. In these forests, the highest $\mathrm{N}_{2} \mathrm{O}$ emission rates coincided with the highest soil moisture and always took place when the soil moisture was higher than 25\% (Merino et al., 2004). Other field and laboratory studies (García-Méndez et al., 1991; Davidson et al., 1993; Kiese and Butterbach-Bahl, 2002) demonstrated that $\mathrm{N}_{2} \mathrm{O}$ emissions were positively correlated with soil moisture content, which is in agreement with our study. In the current study, significant correlations between $\mathrm{N}_{2} \mathrm{O}$ fluxes and soil water content were only found in mudflat and $P$. australis community, but no significant relationship was found in $T$. chinensis and $S$. salsa communities.

As mentioned above, the soil moisture of different positions had no significant difference; the soil grain composition probably resulted in significant difference of EC among the different positions (Sun et al., 2013). In the current study, except for the significantly positive correlations between $\mathrm{N}_{2} \mathrm{O}$ flux and electrical conductivity in surface soil in mudflat and at $15 \mathrm{~cm}$ soil depth in P. australis, no significant relationship was found between $\mathrm{N}_{2} \mathrm{O}$ fluxes and electrical conductivity at other soil depths of the profile, which were different with mostly previous studies that $\mathrm{N}_{2} \mathrm{O}$ emissions had negative correlation with EC (Dalal et al., 2003; Wang et al., 2009). They considered that salinity could inhibit the nitrification and denitrification processes and decrease the production of $\mathrm{N}_{2} \mathrm{O}$. On the contrary, Marton et al. (2012) found that $\mathrm{N}_{2} \mathrm{O}$ production elevated responded to increased salinity in the Satilla River tidal forest soils. One possible explanation for positive effect was that the salinity might not completely inhibit the $\mathrm{N}$ turnover and the activities of nitrifiers and denitrifiers in soil (LV et al., 2008).

Site-level control of $\mathrm{N}_{2} \mathrm{O}$ emission was also attributed to the effects of nutrient status (Sun et al., 2013). Although significant differences in total $\mathrm{C}$ and total $\mathrm{N}$ were found among the four positions, the most correlations between $\mathrm{N}_{2} \mathrm{O}$ emission and total C or total $\mathrm{N}$ were not significant. Positive/negative relationships between $\mathrm{N}_{2} \mathrm{O}$ emissions and total $\mathrm{C}$ or total $\mathrm{N}$ have been reported in previous studies (Allen et al., 2007; Søvik and Kløve, 2007) due to C/N regulations and interactions of other abiotic variables at spatial scale (Huang et al., 2002). In soils, the dominant $\mathrm{N}_{2} \mathrm{O}$ production from both nitrification and denitrification depends on mineralization rates (Ernfors et al., 2007). While mineralization rates are closely linked to the C:N ratio (Gundersen et al., 1998; Ollinger et al., 2002). A C: $N$ ratio value of about 25 has been recognized as a cutoff point below which nitrification in organic material begins (Ollinger et al., 2002) and denitrification preferentially occurs (Ernfors et al., 2007; Saari et al., 2009). The most C:N ratio values in the present study were higher than 25 , which likely lead to no significant correlation between $\mathrm{N}_{2} \mathrm{O}$ emissions and C:N ratio in most soil profile.
$\mathrm{NH}_{4}{ }^{+}-\mathrm{N}$ and $\mathrm{NO}_{3}{ }^{-}-\mathrm{N}$ content mostly had negative correlations with $\mathrm{N}_{2} \mathrm{O}$ emission in the four positions, which was similar with the conclusions drawn by Huang et al. (2002) and Tauchnitz et al. (2008), but was contrary to mostly previous studies (Aelion et al., 1997; Muñoz-Hincapié et al., 2002). In vegetation communities, one possible reason was related to the interactions of vegetation and microorganism (nitrifiers and denitrifiers) that produced negative influences on the transformation of $\mathrm{NH}_{4}{ }^{+}-\mathrm{N}_{\text {or }} \mathrm{NO}_{3}{ }^{-}-\mathrm{N}$ during $\mathrm{N}_{2} \mathrm{O}$ production. Li et al. (2002) indicated that vegetation had great impacts on $\mathrm{N}_{2} \mathrm{O}$ emission through influencing the activities of soil microorganism. Because available $\mathrm{C}, \mathrm{NH}_{4}{ }^{+}-\mathrm{N}$ and $\mathrm{NO}_{3}{ }^{-}-\mathrm{N}$ were important substrates participating in the processes of nitrification and denitrification (Tauchnitz et al., 2008), the production of $\mathrm{N}_{2} \mathrm{O}$ might be inhibited by the available substrates as they were significantly competed by both vegetation absorption and microorganism utilization (Li et al., 2002).

In this study, we observed that the physical and chemical parameters of soil differed among the four positions during the seasons measured. Especially, significant differences in EC, total C, total $\mathrm{N}, \mathrm{NH}_{4}{ }^{+}-\mathrm{N}$ and $\mathrm{NO}_{3}{ }^{-}-\mathrm{N}$ among the four positions. Such differences would be due to the site-specific conditions such as topography, aspect, slope, hydrology, species composition, biomass and coverage of vegetation which determine the magnitudes and variations of $\mathrm{N}_{2} \mathrm{O}$ at spatial scale (Allen et al., 2007; Hirota et al., 2007; Welti et al., 2012). Similarly, annual pattern in $\mathrm{N}_{2} \mathrm{O}$ net emission were found to vary strongly among four different ecosystems located within one site. Our data showed that the mudflat and all communities were $\mathrm{N}_{2} \mathrm{O}$ source and $\mathrm{N}_{2} \mathrm{O}$ fluxes of mudflat was significantly higher than that of vegetations, especially herbage community, such as S. salsa and P. australis. Nykanen et al. (1995) and Maljanen et al. (2007) also showed that the $\mathrm{N}_{2} \mathrm{O}$ emissions from the soils without plants were higher compared to those from cultivated soil, because plants uptake nitrate and limits denitrification. So restoration of saline land through revegetation was necessary to enhance the $\mathrm{N}_{2} \mathrm{O}$ uptake of saline soils.

\section{Conclusions}

Our work provides the first in situ measurements of $\mathrm{N}_{2} \mathrm{O}$ emission in varied saline-alkaline soils of the Yellow River Delta across different seasons. Significant positive correlations were found between $\mathrm{N}_{2} \mathrm{O}$ fluxes and air or soil temperature in surface and subsurface soils of mudflat and different vegetation communities except $P$. australis. Mudflat and $P$. australis showed significant positive/negative relationship between $\mathrm{N}_{2} \mathrm{O}$ emissions and soil water content and EC. While relationships between $\mathrm{N}_{2} \mathrm{O}$ production and soil other properties were only significant in mudflat and $T$. chinensis community. These results probably suggest that other environmental factors or interaction of different factors exerted a larger impact on $\mathrm{N}_{2} \mathrm{O}$ fluxes.

$\mathrm{N}_{2} \mathrm{O}$ emissions in different ecosystems both showed single-peak curves and the maximum occurred in September. The different saline-alkaline soils both acted as $\mathrm{N}_{2} \mathrm{O}$ source. The $\mathrm{N}_{2} \mathrm{O}$ fluxes of mudflat were significantly higher than vegetation communities, especially herbage communities, such as $S$. salsa and $P$. australis. So restoration of saline land through revegetation was necessary to enhance the $\mathrm{N}_{2} \mathrm{O}$ uptake of saline soils.

\section{Acknowledgements}

This work was jointly supported by the Strategic Priority Research Program of the Chinese Academy of Sciences (CAS) (XDA05030404), the National Basic Research Program of China (2013CB430403), One Hundred-Talent Plan of the 
Chinese Academy of Sciences (CAS), the CAS/SAFEA International Partnership Program for Creative Research Teams the Important Direction Project of CAS (KZCX2-YW-JC203), Yantai Science \& Technology Development Project (No.2011016; 2010245), Yantai Double-hundred High-end Talent Plan (XY-003-02), and the Science \& Technology Development Plan of Shandong Province (010GSF10208), Cas Visiting Professorship (2012T1Z0010) and 135 Development Plan of YIC-CAS.

\section{References}

Aelion, C.M., Shaw, J.N., Wahl, M., 1997. Impact of suburbanization on ground water quality and denitrification in coastal aquifer sediments. J. Exp. Mar. Biol. Ecol. 213, 31-51.

Allen, D.E., Dalal, R.C., Rennenberg, H., Meyer, R.L., Reeves, S., Schmidt, S., 2007. Spatial and temporal variation of nitrous oxide and methane flux between subtropical mangrove sediments and the atmosphere. Soil Biol. Biochem. 39, 622-631.

Bedard-Haughn, A., Matson, A.L., Pennock, D.J., 2006. Land use effects on gross nitrogen mineralization, nitrification, and $\mathrm{N}_{2} \mathrm{O}$ emissions in ephemeral wetlands. Soil Biol. Biochem. 38, 3398-3406.

Breuer, L., Papen, H., Butterbach-Bahl, K., 2000. $\mathrm{N}_{2} \mathrm{O}$ emission from tropical forest soils of Australia. J. Geophys. Res. 105, 26353-26367.

Cai, Z.C., Laughlin, R.J., Stevens, R.J., 2001. Nitrous oxide and dinitrogen emissions from soil under different water regimes and straw amendment. Chemosphere 42, 113-121.

Crill, P.M., Keller, M., Weitz, A., Grauel, B., Veldkampz, E., 2000. Intensive field measurements of nitrous oxide emissions from a tropical agricultural soil. Global Biogeochem. Cycles 14, 85-95.

Dalal, R.C., Wang, W.J., Robertson, G.P., Parton, W.J., 2003. Nitrous oxide emission from Australian agricultural lands and mitigation options: a review. Aust. J. Soil Res. 41, 165-195.

Davidson, E.A., 2009. The contribution of manure and fertilizer nitrogen to atmospheric nitrous oxide since 1860. Nat. Geosci. 2, 659-662.

Davidson, E.A., Keller, M., Erickson, H.E., Verchot, L.V., Veldkamp, E., 2000. Testing a conceptual model of soil emissions of nitrous and nitric oxides. Bioscience 50, $667-680$.

Davidson, E.A., Matson, P.A., Vitousek, P.M., Riley, R., Dunkin, K., Garcia-Mendez, G., Maass, J.M., 1993. Processes regulating soil emissions of $\mathrm{NO}$ and $\mathrm{N}_{2} \mathrm{O}$ in a seasonally dry tropical forest. Ecology 74, 130-139.

Ernfors, M., von Arnold, K., Stendahl, J., Olsson, M., Klemedtsson, L., 2007. Nitrous oxide emissions from drained organic forest soils - an up-scaling based on C:N ratios. Biogeochemistry 84, 219-231.

García-Méndez, G., Maass, J.M., Matson, P.A., Vitousek, P.M., 1991. Nitrogen transformations and nitrous oxide flux in a tropical deciduous forest in Mexico. Oecologia 88, 362-366.

Gharahi Ghehi, N., Werner, C., Cizungu Ntaboba, L., Mbonigaba Muhinda, J.J., Van Ranst, E., Butterbach-Bahl, K., Kiese, R., Boeckx, P., 2012. Spatial variations of nitrogen trace gas emissions from tropical mountain forests in Nyungwe, Rwanda. Biogeosciences 9, 1451-1463.

Ghassemi, F., Jakeman, A.J., Nix, H.A., 1995. Salinisation of Land and Water Resources: Human Causes, Extent, Management and Case Studies. University of New South Wales Press Ltd., Canberra, Australia.

Grant, R.F., Pattey, E., 2003. Modelling variability in $\mathrm{N}_{2} \mathrm{O}$ emissions from fertilized agricultural fields. Soil Biol. Biochem. 35, 225-243.

Gundersen, P., Emmett, B.A., Kjønaas, O.J., Koopmans, C.J., Tietema, A., 1998. Impact of nitrogen deposition on nitrogen cycling in forests: a synthesis of NITREX data. Forest Ecol. Manag. 101, 37-55.

Hirota, M., Senga, Y., Seike, Y., Nohara, S., Kunii, H., 2007. Fluxes of carbon dioxide, methane and nitrous oxide in two contrastive fringing zones of coastal lagoon, Lake Nakaumi, Japan. Chemosphere 68, 597-603.

Huang, Y., Jiao, Y., Zong, L.G., Zhou, Q.S., Zheng, X.H., Ronald, L.S., 2002. $\mathrm{N}_{2} \mathrm{O}$ emission from wheat cultivated soils as influenced by soil physico-chemical properties. Acta Sci. Circum. 22, 598-602.

IPCC, 2001. Climate Change. The Scientific Basis. Cambridge University Press, Cambridge.

Kachenchart, B., Jones, D.L., N.G., Edwards-Jones, G., Limsakul, A., 2012. Seasonal nitrous oxide emissions from different land uses and their controlling factors in a tropical riparian ecosystem. Agric. Ecosyst. Environ. 158, 15-30.

Kiese, R., Butterbach-Bahl, K., 2002. $\mathrm{N}_{2} \mathrm{O}$ and $\mathrm{CO}_{2}$ emissions from three different tropical forest sites in the wet tropics of Queensland, Australia. Soil Biol. Biochem. 34, 975-987.

Klemedtsson, L., Klemedtsson, Å.K., Moldan, F., Weslien, P., 1997. Nitrous oxide emission from Swedish forest soils in relation to liming and simulated increased N-deposition. Biol. Fertil. Soils 25, 290-295.

Li, J., Yu, Q., Tong, X.J., 2002. Vegetation - an important source of atmospheric $\mathrm{N}_{2} \mathrm{O}$. Earth Sci. Front. 9, 112.

Liu, X.Y., Qu, J.J., Li, L.Q., Zhang, A.F., Zheng, J.F., Zheng, J.W., Pan, G.X., 2012. Can biochar amendment be an ecological engineering technology to depress $\mathrm{N}_{2} \mathrm{O}$ emission in rice paddies? - a cross site field experiment from South China. Ecol. Eng. $42,168-173$.
Long, K.D., Flanagan, L.B., Cai, T., 2010. Diurnal and seasonal variation in methane emissions in a northern Canadian peatland measured by eddy covariance. Globa Change Biol. 16, 2420-2435.

Lv, Y.H., Bai, H., Jiang, Y., Yu, J.H., 2008. Study of nitrification activity and impact factors of wetland in Yellow river delta. J. Oceanol. Limnol. 2, 61-66.

Maljanen, M., Hytoenen, J., Maekiranta, P., Alm, J., Minkkinen, K., Laine, J., Martikainen, P.J., Laiho, R., 2007. Greenhouse gas emissions from cultivated and abandoned organic croplands in Finland. Boreal Environ. Res. 12, 133-140.

Maljanen, M., Liikanen, A., Silvola, J., Martikainen, P.J., 2003. Nitrous oxide emissions from boreal organic soil under different land-use. Soil Biol. Biochem. 35 689-700.

Marton, J.M., Herbert, E.R., Craft, C.B., 2012. Effects of salinity on denitrification and greenhouse gas production from laboratory-incubated tidal forest soils. Wetlands 32, 347-357.

Merino, A., Pérez-Batallón, P., Macías, F., 2004. Responses of soil organic matter and greenhouse gas fluxes to soil management and land use changes in a humid temperate region of southern Europe. Soil Biol. Biochem. 36, 917-925.

Mou, X.J., Sun, Z.G., Wang, L.L., Wang, C.Y., 2011. Nitrogen cycle of a typical Suaeda salsa marsh ecosystem in the Yellow River estuary. J. Environ. Sci. 23, 958-967.

Muñoz-Hincapié, M., Morell, J.M., Corredor, J.E., 2002. Increase of nitrous oxide flux to the atmosphere upon nitrogen addition to red mangroves sediments. Mar. Pollut. Bull. 44, 992-996.

Nykanen, H., Alm, J., Lang, K., Silvola, J., Martikainen, P.J., 1995. Emissions of $\mathrm{CH}_{4}, \mathrm{~N}_{2} \mathrm{O}$ and $\mathrm{CO}_{2}$ from a virgin fen and a fen drained for grassland in Finland. J. Biogeogr. 22, 351-357.

Ollinger, S.V., Smith, M.L., Martin, M.E., Hallett, R.A., Goodale, C.L., Aber, J.D., 2002 Regional variation in foliar chemistry and $\mathrm{N}$ cycling among forests of diverse history and composition. Ecology 83, 339-355.

Regina, K., Silvola, J., Martikainen, P.J., 1999. Short-term effects of changing water table on $\mathrm{N}_{2} \mathrm{O}$ fluxes from peat monoliths from natural and drained boreal peatlands. Global Change Biol. 5, 183-189.

Søvik, A.K., Kløve, B., 2007. Emission of $\mathrm{N}_{2} \mathrm{O}$ and $\mathrm{CH}_{4}$ from a constructed wetland in southeastern Norway. Sci. Total Environ. 380, 28-37.

Saari, P., Saarnio, S., Kukkonen, J.V.K., Akkanen, J., Heinonen, J., Saari, V., Alm, J., 2009 DOC and $\mathrm{N}_{2} \mathrm{O}$ dynamics in upland and peatland forest soils after clear-cutting and soil preparation. Biogeochemistry 94, 217-231.

Sahrawat, K.L., Keeney, D.R., 1986. Nitrous oxide emission from soils. Adv. Soil Sci., vol. 4. Springer, New York, pp. 103-148.

Schaufler, G., Kitzler, B., Schindlbacher, A., Skiba, U., Sutton, M.A., ZechmeisterBoltenstern, S., 2010. Greenhouse gas emissions from European soils under different land use: effects of soil moisture and temperature. Eur. J. Soil Sci. 61 683-696.

Schindlbacher, A., Zechmeister-Boltenstern, S., Butterbach-Bahl, K., 2004. Effects of soil moisture and temperature on $\mathrm{NO}, \mathrm{NO}_{2}$, and $\mathrm{N}_{2} \mathrm{O}$ emissions from European forest soils. J. Geophys. Res. 109, D17302.

Silva, C.C., Guido, M.L., Ceballos, J.M., Marsch, R., Dendooven, L., 2008. Production of carbon dioxide and nitrous oxide in alkaline saline soil of Texcoco at different water contents amended with urea: a laboratory study. Soil Biol. Biochem. 40 $1813-1822$.

Smith, K.A., Ball, T., Conen, F., Dobbie, K.E., Massheder, J., Rey, A., 2003. Exchange of greenhouse gases between soil and atmosphere: interactions of soil physica factors and biological processes. Eur. J. Soil Sci. 54, 779-791.

Song, C.C., Xu, X.F., Tian, H.Q., Wang, Y.Y., 2009. Ecosystem-atmosphere exchange of $\mathrm{CH}_{4}$ and $\mathrm{N}_{2} \mathrm{O}$ and ecosystem respiration in wetlands in the Sanjiang Plain, Northeastern China. Global Change Biol. 15, 692-705.

Song, C.C., Zhang, J.B., Wang, Y.Y., Wang, Y.S., Zhao, Z.C., 2008. Emission of $\mathrm{CO}_{2}, \mathrm{CH}_{4}$ and $\mathrm{N}_{2} \mathrm{O}$ from freshwater marsh in northeast of China. J. Environ. Manage. 88, 428-436.

Stevens, R.J., Laughlin, R.J., Malone, J.P., 1998. Soil pH affects the processes reducing nitrate to nitrous oxide and di-nitrogen. Soil Biol. Biochem. 30, 1119-1126.

Sun, Z.G., Wang, L.L., Tian, H.Q., Jiang, H.H., Mou, X.J., Sun, W.L., 2013. Fluxes of nitrous oxide and methane in different coastal Suaeda salsa marshes of the Yellow River estuary, China. Chemosphere 90, 856-865.

Tang, X.L., Liu, S.G., Zhou, G.Y., Zhang, D.Q., Zhou, C.Y., 2006. Soil-atmospheric exchange of $\mathrm{CO}_{2}, \mathrm{CH}_{4}$, and $\mathrm{N}_{2} \mathrm{O}$ in three subtropical forest ecosystems in southern China. Global Change Biol. 12, 546-560.

Tauchnitz, N., Brumme, R., Bernsdorf, S., Meissner, R., 2008. Nitrous oxide and methane fluxes of a pristine slope mire in the German National Park Harz Mountains. Plant Soil 303, 131-138.

Tian, J.Y., Wang, X.F., Cai, X.J., 2005. Protection and Restoration Technique of Wetland Ecosystem in Yellow River Delta. China Ocean University Press, Qingdao.

Wang, D.Q., Chen, Z.L., Sun, W.W., Hu, B.B., Xu, S.Y., 2009. Methane and nitrous oxide concentration and emission flux of Yangtze Delta plain river net. Sci. China Ser. B 52, 652-661.

Wang, D.Q., Chen, Z.L., Wang, J., Xu, S.Y., Yang, H.X., Chen, H., Yang, L.Y., Hu, L.Z. 2007. Summer-time denitrification and nitrous oxide exchange in the intertida zone of the Yangtze Estuary. Estuar. Coast. Shelf Sci. 73, 43-53.

Wang, X.H., Yu, J.B., Zhou, D., Dong, H.F., Li, Y.Z., Lin, Q.X., Guan, B., Wang, Y.L., 2012 Vegetative ecological characteristics of restored reed (Phragmites australis) wetlands in the Yellow River Delta, China. Environ. Manage. 49, 325-333.

Welti, N., Bondar-Kunze, E., Singer, G., Tritthart, M., Zechmeister-Boltenstern, S. Hein, T., Pinay, G., 2012. Large-scale controls on potential respiration and denitrification in riverine floodplains. Ecol. Eng. 42, 73-84. 
Wrage, N., Velthof, G.L., Van Beusichem, M.L., Oenema, O., 2001. Role of nitrifier denitrification in the production of nitrous oxide. Soil Biol. Biochem. 33, 1723-1732.

Xing, S.J., Zhang, J.F., 2006. Land Degradation Mechanism and Ecological Rehabilitation Techniques in Yellow River Delta Region. China Forestry Publishing House, Beijing.

Zhang, H.H., Li, W.X., Cai, Z.C., Zhang, Y., Feng, Y.H., Zhang, H.L., He, F., 2013. Landfill $\mathrm{CH}_{4}$ oxidation and $\mathrm{N}_{2} \mathrm{O}$ emissions by aged refuse, Effects of wastewater $\mathrm{NH}_{4}{ }^{+}-\mathrm{N}$ incubation, heavy metals and pH. Ecol. Eng. 53, 243-249.
Zheng, X.H., Wang, M.X., Wang, Y.S., Shen, R.X., Gou, J., Li, J., Jin, J.S., Li, L.T., 2000. Impacts of soil moisture on nitrous oxide emission from croplands: a case study on the rice-based agro-ecosystem in Southeast China. Chemosphere 2, 207-224.

Zhu, R.B., Liu, Y.S., Ma, J., Xu, H., Sun, L.G., 2008. Nitrous oxide flux to the atmosphere from two coastal tundra wetlands in eastern Antarctica. Atmos. Environ. 42, 2437-2447. 